\title{
$\mathrm{DFT}$ 에 의한 회전자 위치 검출 방법을 사용한 레졸버 인터페이스에 관한 연구 \\ 황락훈 $^{1^{*}}$, 나승권 $^{2}$, 최기호 ${ }^{3}$ \\ ${ }^{1}$ 세명대학교 전기공학과, ${ }^{2}$ 한국폴리텍 ॥ㄷ대학 의용공학과, ${ }^{3}$ 한국폴리텍 II대학 전기제어학과
}

\section{A Study on the Resolver Interface using a Rotor Position Detector Method with DFT}

\author{
Lark-Hoon Hwang ${ }^{1 *}$, Seung-kwon $\mathrm{Na}^{2}$ and Gi-Ho $\mathrm{Choi}^{3}$ \\ ${ }^{1}$ Dept.of Electrical Engineering, Semyoung University \\ ${ }^{2}$ Dept.of Biomedical Engineering, korea Polytechnics III College \\ ${ }^{3}$ Dept.of Electric Control Engineering,korea Polytechnics III College
}

\begin{abstract}
요 약 전동기를 제어하기 위한 속도를 검출하는 장치로 일반적으로 광학적 엔코더가 많이 사용되고 있으며 레졸버 는 구조적으로 엔코더를 전동기에 장착하기가 어려운 경우에 사용하고 있다. 따라서 레졸버는 엔코더와 비교하여 가 격면에서 불리하지만 회전자의 절대위치를 검출하기 때문에 자극의 위치를 기준으로 제어하는 경우에 유용하다. 본 연구는 레졸버에 의한 전동기의 회전속도 및 위치를 검출하는 방법으로 최소한의 하드웨어인 필터를 사용하고 프로 그램에 의한 디지털방법의 속도검출기에 관한 것이다.
\end{abstract}

\begin{abstract}
Generally, a optical encoder is used to detect velocity for controling the electronic motor, the resolver is used when it is hard structurally to adjust encoder to electronic motor. so, the resolver has weakness in price in compare with encoder, but in case of controling the position of a magnetic polar, the resolver has stead detecting the absolute position of a rotator. This study is about the digital programing velocity detector which uses a minimum hardware : filter for detecting the revolve speed and rotor position of the motor by means of the resolver.
\end{abstract}

Key Words : Electric motor, Resolver, Detecting the revolve speed

\section{1. 서론}

전동기를 제어할 때 회전정보는 정밀하고 빠르게 검지 되어야 한다. 속도검출장치는 저렴한 가격과 회전자의 위 치와 속도를 정확하게 측정하고 융통성 있는 제어방법을 허용하여야 한다. 또한 회전하는 장치의 제어에 있어서 회전하는 축에 설치한 검출장치에 의하여 회전체의 움직 임 또는 회전위치를 정확하게 측정하여야 한다. 이러한 방법으로 채택되고 사용되어 온 검출기로 레졸버와 엔코 더가 있으며 이 검출기들은 서로 장점과 단점을 갖고 있 다.
레졸버와 엔코더는 절대위치에 대한 직접검지기능의 가능여부로 구분될 수 있다. 레졸버는 회전자의 절대위치 를 직접적으로 검지하여 회전자의 위치변화에 의하여 회 전방향과 회전속도를 계산하게 된다. 엔코더는 2 상의 펄 스에 의한 회전방향의 검지와 기준펄스의 순간으로부터 계수하는 펄스 수에 의하여 상대적인 위치를 계산 하여 야 한다. 그러므로 엔코더를 사용한 $\mathrm{AC}$ 서보 등의 제어 에 있어서 회전자 절대위치의 정보제공을 위하여 별도로 3 개의 엔코더 트랙이 추가된 엔코더가 사용하고 있 다.[1-5]

엔코더는 회전하는 디스크로 부터 1 회전 당 10,000 펄

"교신저자 : 황락훈(lhhwang@semyung.ac.kr)

접수일 11년 07월 12일 수정일 (1차 11년 08월 16일, 2차 11년 09월 14일, 3차 11년 09월 16일, 11년 09월 30일) 게재확정일 11년 10월 06일 
스 이상의 높은 정밀성의 확보가 되는 특징을 갖고 있다. 레졸버는 기본적으로 $\mathrm{A} / \mathrm{D}$ 변환에 의한 $\mathrm{RD}$ 컨버터가 사 용되고 있다.

레졸버는 $90^{\circ}$ 의 위상차를 갖고 설치된 두 개의 출력권 선이 있고 회전축의 정보를 여자신호에 의하여 변조된 두 신호로부터 회전속도를 추정하는 방법이 일반적으로 사용되고 있다.

동기전동기와 같이 제어기가 회전자의 위치를 기준으 로 제어를 하는 경우에 위치정보는 매우 중요한 요소이 다. 따라서 견인전동기를 차륜에 직결한 구조로 동기전동 기를 사용할 때 저 분해능의 엔코더를 사용하는 경우는 회전자의 위치를 정확하게 추정하는 기술이 사용되어야 정확한 속도제어가 계산에 의해 제어되므로 본 연구에서 는 레졸버 방식을 채택하여 사용하였다.[6-10]

위치 및 속도검출에 있어서 정밀한 측정은 제어기의 성능을 좌우하는 중요한 요소가 되고 있으며 이들의 측 정은 매우 중요하다고 여겨진다.

레졸버를 사용하는 경우 아날로그신호에 포함하고 있 는 노이즈의 문제는 위치정보에 오차를 수반하게 한다. 레졸버의 경우 $10[\mathrm{kHz}]$ 의 신호를 사용하도록 되어 있으 며 출력신호인 위치정보도 입력 여자전류의 주파수로 변 조된 신호를 출력하고 있다. 따라서 회전자의 위치정보인 2상 출력의 $\cos , \sin$ 파형으로 복조하고 이들 파형에 포함 된 노이즈를 제거하여 위치를 계산하여야 한다.

본 연구에서는 위치와 속도를 추정하는 관측기를 사용 하였으며 위치와 속도를 측정하기 위하여 사용한 레졸버 의 인터페이스는 6 가지의 기능을 갖는 블록으로 구성한 다.

첫째로 레졸버를 여자 시키기 위한 발진기와 아날로그 증폭기를 구성하고, 둘째는 샘플러를 구동하기 위한 신호 의 발생회로와 셋째는 레졸버 신호의 필터회로, 넷째는 샘플링회로 그리고 다섯째는 아날로그신호의 전송과 $\mathrm{A} / \mathrm{D}$ 변환, 여섯째는 디지털 관측기 시스템으로 구성한다.

따라서, 레졸버를 사용할 때 RD 컨버터는 up/down 카 운터와 $\mathrm{D} / \mathrm{A}$ 변환기로 구성한 하드웨어적인 $\mathrm{RD}$ 컨버터가 개발되어 있다. 레졸버의 신호처리에 있어서 복조 후 회 전자의 위치를 계산하고 속도를 추정하는 방법 추정기의 오차검출기에 복조의 기능을 갖는 방법으로 되어 있 다.[3-5]

속도의 추정방법은 관측기를 사용하는 방법들이 알려 져 있다.[1-2] 제반정수의 오차가 있더라도 관측기가 추 정하는 범위에서 우수한 특성을 갖게 되지만 적용하는 대상 시스템의 부하관성 또는 부하가 크게 변하는 경우 는 유용하지 않게 되는 문제를 갖고 있다.

본 연구에서는 DFT를 사용하여 기본파를 계산하는 과
정으로 복조된 2상 신호에 의하여 회전자의 위치를 직접 계산하고 PI제어기에 의하여 추정된 속도는 12 [bit] 이상 의 분해능력 을 얻었다. 제어기에서 프로그램에 의하여 속도를 변화시키는 방법으로 스텝응답을 측정하고 응답 을 관찰하면서 속도추정기인 PI제어기의 이득을 결정하 였다. 속도추정기의 이득은 응답성과 정밀성이 관계가 있 으므로 전동기 제어 프로그램의 일부분으로 사용하였으 나 속도검출기 전용의 경우와 같이 샘플링간격을 짧게 할 수 있다면 더욱 정밀성의 향상이 가능할 것이다. 따라 서 부하의 조건과 관계없는 속도의 추정이므로 범용의 속도검출기 또는 부하 및 관성이 변하는 장치에 응용이 가능한 방법에 적용 할 수 있다.

\section{2. 레졸버 인터페이스}

\section{1 레졸버의 구조}

레졸버는 회전자의 절대위치를 측정할 수 있으며 기본 적으로 회전기기와 같은 구조로 되어 있다. 사용된 레졸 버의 구조는 그림 1 과 같다.

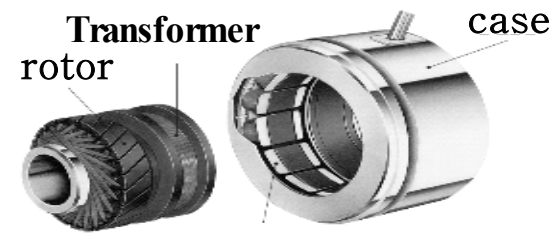

[그림 1] 레졸버의 구조

[Fig. 1] Structure of resolver

고정자에는 여자권선과 출력권선이 있고 고주파수의 교류로 여자 시키고 출력권선에 같은 주파수의 교류전압 을 유기시킨다. 출력전압은 회전자의 각(위치)에 따라 변 화하는 2상 출력상태이며 이 전압으로 회전자의 위치를 계산한다.

그림 2 는 그림 1 의 레졸버에 대한 회로를 나타낸 것이 며 $\mathrm{R}_{1}-\mathrm{R}_{2}$ 에 여자전압을 인가한다. 출력권선은 $\mathrm{S}_{1} \mathrm{~S}_{3}$ 와 $\mathrm{S}_{2} \mathrm{~S}_{4}$ 로 회전자의 위치에 따라 다른 전압을 출력한다. 일 반적으로 레졸버는 브러시가 없는 구조로 되어 있으며 회전변압기에 의하여 회전자권선을 여자 시키는 구조와 회전자에 권선이 없는 구조가 있다. 외부의 회로와 사용 은 두 가지 모두 같은 방법으로 사용이 가능하다. 


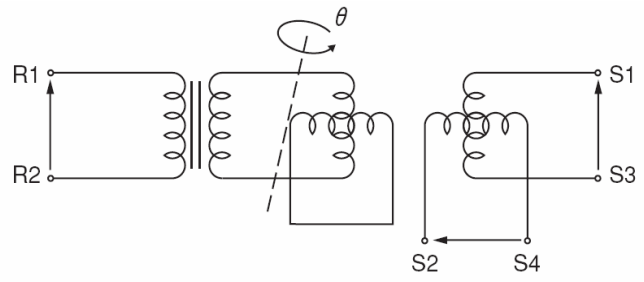

Excitation side Output side(stator)

[그림 2] 레졸버와 입출력신호

[Fig. 2] Input output signal of resolver

여자전압과 출력은 식(1)과 같이 나타내고 있다.

$$
\left\{\begin{array}{l}
E_{R 1-R 2}=E \sin \omega t \\
E_{S 1-S 3}=K E_{R 1-R 2} \cos \theta \\
E_{S 2-S 4}=K E_{R 1-R 2} \sin \theta
\end{array}\right.
$$$$
K=\text { 여자변압기의 권수비 }
$$

그림 3 은 레졸버의 회전자가 회전하고 있을 때 출력파 형을 나타낸 것이다. 입력인 여자전압으로 변조된 출력을 나타내고, 위치의 정보는 출력파형에 포함하고 있다. 그 러므로 출력파형의 최대값을 샘플링 할 수 있다면 이 전 압으로 회전자의 위치를 계산할 수 있는 2상 출력을 얻을 수 있다.

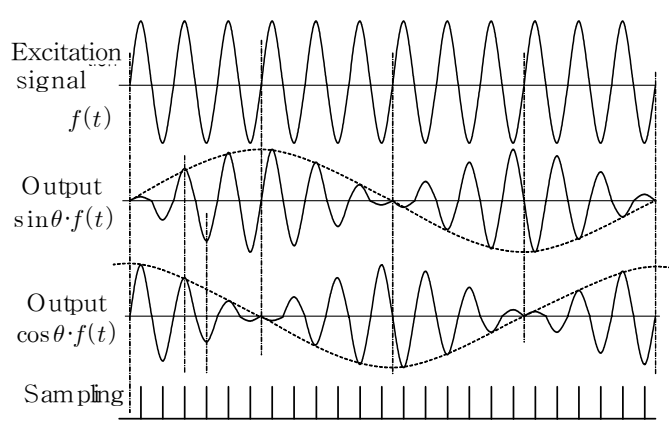

[그림 3] 레졸버의 출력과 샘플링

[Fig. 3] Output and sampling of resolver

\section{2 속도 검출기 설계 및 여자회로와 신호처리}

\subsection{1 속도 검출기 설계}

여자전압은 정현파를 사용하므로 윈 브리지에 의하여 정현파를 발생하고 이를 증폭하여 여자전원으로 사용한 다. 검출기(레졸버)는 전력변환기에 의하여 구동되는 전 동기에 부착되어 누설자속 등에 의한 노이즈가 포함하는 신호를 출력하므로 노이즈를 제거하기 위한 필터와 차동
입력회로를 필수적으로 사용해야 한다. 따라서 여자신호 와 출력신호는 위상지연이 있게 되고 사용되는 필터의 전달함수에 관계없이 최대출력전압이 샘플링 되어야 하 지만 본 연구에서는 그림 4 와 같은 블록을 사용하여 고정 된 필터에 대하여 동작하는 회로를 설계하였다.

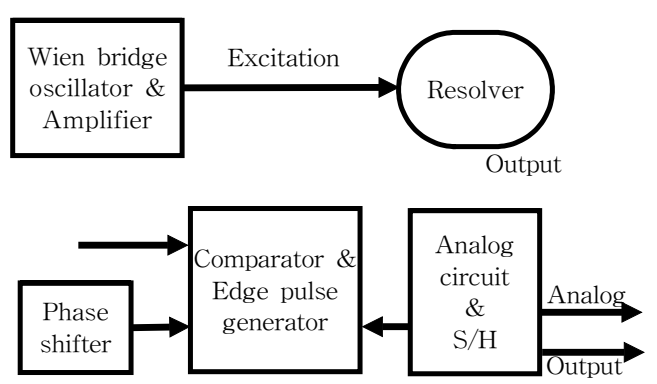

[그림 4] 레졸버 신호처리

[Fig. 4] resolver signal processing

그림 5 는 샘플링방법에 의하여 레졸버의 출력을 복조 하는 방법을 설명한 것이다. 필터의 사용으로 지연된 신 호에서 최대값을 샘플링하려면 필터의 지연을 고려한 샘 플링펄스가 요구된다. 여자전압을 기준으로 했을 때 필터 후 레졸버의 출력신호는 그림 5 와 같이 지연된 파형이 된 다. 샘플링펄스의 발생은 펄스의 발생시점까지 여자전압 파형의 위상을 이동시키는 아날로그 방법을 사용한다.

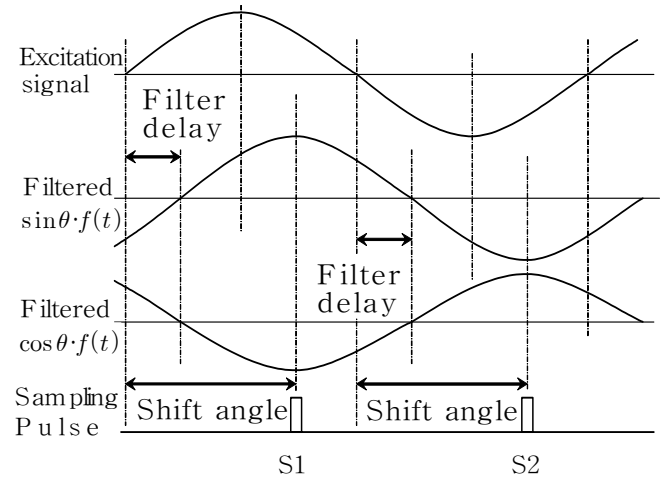

[그림 5] 필터의 지연시간과 샘플링

[Fig. 5] Delay time of filter and sampling

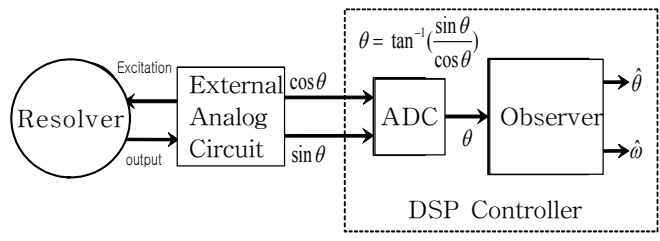

[그림 6] 회전자 위치와 속도의 검출

[Fig. 6] Rotor position and detection of speed 
그림 6 은 회전자 위치와 속도의 검출기를 나타내었다. 검출기의 아날로그회로의 출력은 회전자의 위치정보인 $\sin , \cos$ 파형이 되고 이 파형은 $\mathrm{A} / \mathrm{D}$ 변환기에 의하여 제 어기의 디지털신호로 변환한다.

\subsection{2 여자전압의 발생}

그림 4의 블록도에 대한 아날로그 회로를 설계하기 위 해 검출기의 아날로그회로의 출력은 회전자의 위치정보 인 $\sin , \cos$ 파형이 되고 이 파형은 $\mathrm{A} / \mathrm{D}$ 변환기에 의하여 제어기의 디지털신호로 변환한다. 정현파를 얻기 위하여 윈 브리지 발진회로를 사용하였고, 윈 브리지 발진기는 그림 7의 회로에서 식 (2)와 같다.

$$
f=\frac{1}{2 \pi R C}
$$

식 (2)의 주파수로 정현파를 발생하며 발진조건으로는 증폭이득이 3 으로 되어야 한다. 한편 제너다이오드는 역 전류가 일반다이오드보다 크고 제너전압보다 낮은 전압 에서 전압에 따라 저항이 변화하는 특성을 얻을 수 있다. 따라서 그림 7의 회로에서 $R_{g 2}$ 를 $2 R_{g 1}$ 보다 약간 크게 선정하면 $R_{g 2}$ 와 병렬로 연결된 역 직렬 제너다이오드의 특성에 의하여 정해지는 점에서 안정된 발진을 하게 된 다. 또 여자전압의 크기는 식 (3)과 같다.

$$
E_{R \max }=O S C_{\text {signal max }} \times \frac{R_{f 2}}{R_{f 1}}
$$

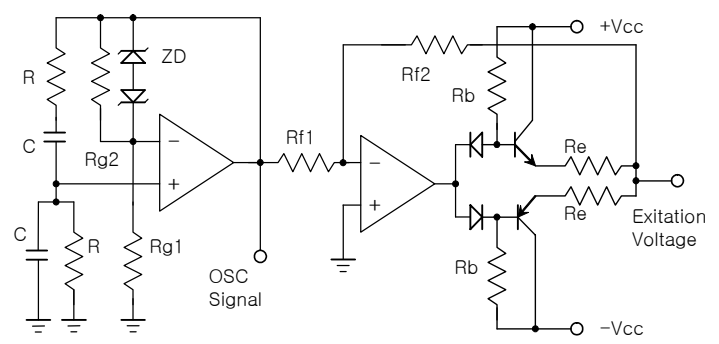

[그림 7] 윈 브리지와 여자전압의 발생회로

[Fig. 7] Wein bridge and generating circuits of exite voltage

\subsection{3 레졸버 신호 입력회로}

레졸버는 전동기의 축에 부착되므로 전력변환기의 스 위칭 노이즈 등이 흡입될 수 있기 때문에 그림 8 과 같은 차동입력회로를 갖는 필터를 사용한다.

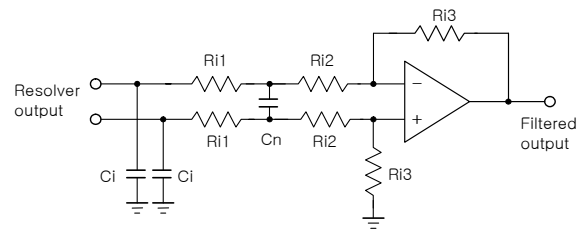

[그림 8] 필터회로 신호

[Fig. 8] Signal of filter circuits

필터의 차단주파수와 증폭이득은 식 (4)와 같다.

$$
\left\{\begin{array}{l}
\omega_{0} \fallingdotseq \frac{1}{2 \pi R_{i l} C_{N}} \\
G \fallingdotseq \frac{R_{i 3}}{R_{i 1}+R_{i 2}}
\end{array}\right.
$$

\subsubsection{S/H 회로}

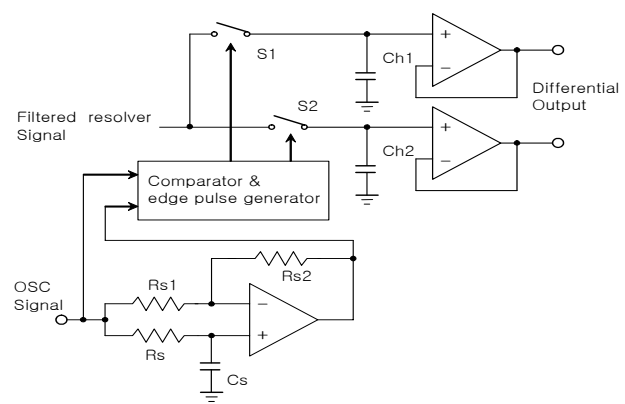

[그림 9] 샘플링펄스의 발생과 $\mathrm{S} / \mathrm{H}$ 회로

[Fig. 9] Generation of sampling pulse and $\mathrm{S} / \mathrm{H}$ circuits

그림 5에서 샘플링하려는 신호는 여자전압이 $(+)$ 인 구 간과 (-)인 구간에서 극성이 다르게 된다. 또 이번 연구에 서는 아날로그 신호를 제어기로 전송하는 방법을 사용하 고자 하기 때문에 차동신호를 발생하여야 한다. 따라서 그림 5에서와 같이 S1과 S2의 펄스를 별도로 출력하여야 한다.그림 5에서와 같이 샘플링 펄스는 위상시프트 회로 에 의하여 발생시키므로 그림 9에서 위상 시프터의 이득 은 식 (5)와 같다.

$$
G=1<-2 \tan ^{-1}\left(\omega C_{s} R_{s}\right)
$$

식(5)와 같이 필터에 의한 지연이 발생하므로 식(4)를 고려한 계산식으로 결정한다. 또 실험으로 확인하고 수정 하는 절차를 거쳐야 한다. 그림 9에서 비교기는 OSC 신 호파형 및 이것이 위상시프트 된 두 파형을 정형한다. 위 상시프트 된 파형의 0 점에서 $\mathrm{S} 1, \mathrm{~S} 2$ 의 두 펄스를 발생시 
키고 $\mathrm{OSC}$ 신호파형의 정형신호로 $\mathrm{S} 1$ 과 $\mathrm{S} 2$ 를 분리시킨 다. 아날로그출력은 신호전송을 위하여 차동신호를 출력 하도록 한다.

\subsection{5 위치와 속도의 추정 및 속도 추정기}

레졸버로 부터 얻어진 $\cos , \sin$ 파형은 제어기에 디지 털신호로 입력되고 프로그램에 의하여 회전자의 위치와 회전속도가 계산된다. 회전자의 위치를 계산하면 식(6)과 같다.

$$
\theta=\tan ^{-1}\left(\frac{\sin \theta}{\cos \theta}\right)
$$

식 (6)에 의한 회전자의 위치는 노이즈가 포함되어 있 으므로 위치정보는 부정확성을 배재할 수 없다. 이로부터 위치를 추정하는 방법이 필요하게 되므로 전동기의 운동 방정식을 고찰한다. 관성을 갖는 회전체는 식 (7)과 같다.

$$
\left\{\begin{array}{l}
\frac{d \theta}{d t}=\omega \\
\frac{d \omega}{d t}=\frac{1}{J}\left(T-T_{L}\right)
\end{array}\right.
$$

식 (7)에서 측정이 가능한 변수는 식(6)으로 계산된 회 전자의 위치이므로 식(7)의 시스템에 대한 전 차원 관측 기는 식 (8)과 같다.

$$
\left\{\begin{array}{l}
\frac{d \hat{\theta}}{d t}=\omega+g_{1}(\theta-\hat{\theta}) \\
\frac{d \hat{\omega}}{d t}=\frac{1}{J}\left(T-T_{L}\right)+g_{2}(\theta-\hat{\theta})
\end{array}\right.
$$

식(7)과 식(8)에서 각각 두 번째 속도 식은 회전체의 관성과 전동기의 토크 및 부하토크를 포함하고 있으며 이에 대한 정보는 검출기에 포함할 수 없다. 따라서 관성 과 토크에 관련된 항을 소거하기 위하여 식(9)와 같이 상 태 궤환에 PI제어기를 사용하여 위치와 회전속도를 추정 한다.

$$
\left\{\begin{array}{l}
\frac{d \hat{\theta}}{d t}=\omega+g_{1}(\theta-\hat{\theta}) \\
\frac{d \hat{\omega}}{d t}=\left(g_{p}+\frac{g_{i}}{s}\right)(\theta-\hat{\theta})
\end{array}\right.
$$

식(9)의 두 번째식의 우변에서 식 (10)과 같다.

$$
G=g_{i}(\theta-\hat{\theta})
$$

식(9)는 식 (11)과 같이 나타낼 수 있다.

$$
\left\{\begin{array}{l}
\frac{d \hat{\theta}}{d t}=\hat{\omega}+g_{1}(\theta-\hat{\theta}) \\
\frac{d \hat{\omega}}{d t}=\hat{G}+g_{p}(\theta-\hat{\theta}) \\
\frac{d \hat{G}}{d t}=g_{i}(\theta-\hat{\theta})
\end{array}\right.
$$

$\mathrm{PMSM}$ 을 구동하는 경우 회전자의 위치정보는 매우 중요하게 된다. 식(11)에서 $G$ 는 회전시스템의 관성과 회 전력에 관계되는 가속도가 된다. 회전자의 위치가 정상상 태에서 실제 시스템에 수렴한다고 하더라도 가속도를 정 확하게 추정하지 못한다면 회전속도가 변화하는 가속과 감속상태 에서는 오차를 수반하는 경우가 존재할 수 있 다. 따라서 식 (11)의 궤환 이득은 반복실험에 의하여 정 할 필요가 있다. 식(9), 또는 식(11)에 의하여 회전자의 위 치와 회전속도를 추정하는 검출기의 관측기는 그림 10 과 같은 블록도와 같이 나타낼 수 있다.

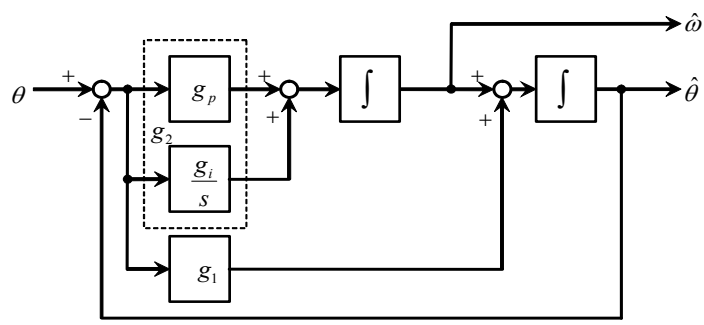

[그림 10] 회전자의 위치와 속도의 검출 블록도

[Fig. 10] Block diagram of Rotor position and detection of speed

회전속도의 추정방법은 관측기를 이용하는 방법과 관 측기를 사용하지 않는 방법들이 소개되고 있다. 관측기를 사용하는 경우 부하 또는 관성이 변하는 시스템일 때 관 측기의 상수가 변하게 되고 사용하고자 하는 대상의 장 치가 달라지면 상수를 변경시켜야 하므로 범용의 속도검 출방법이 되지 않는다. 따라서 부하 및 관성을 고려하지 않는 RD 컨버터에서는 관측기를 사용하지 않는 방법들 이 사용되고 있다. 


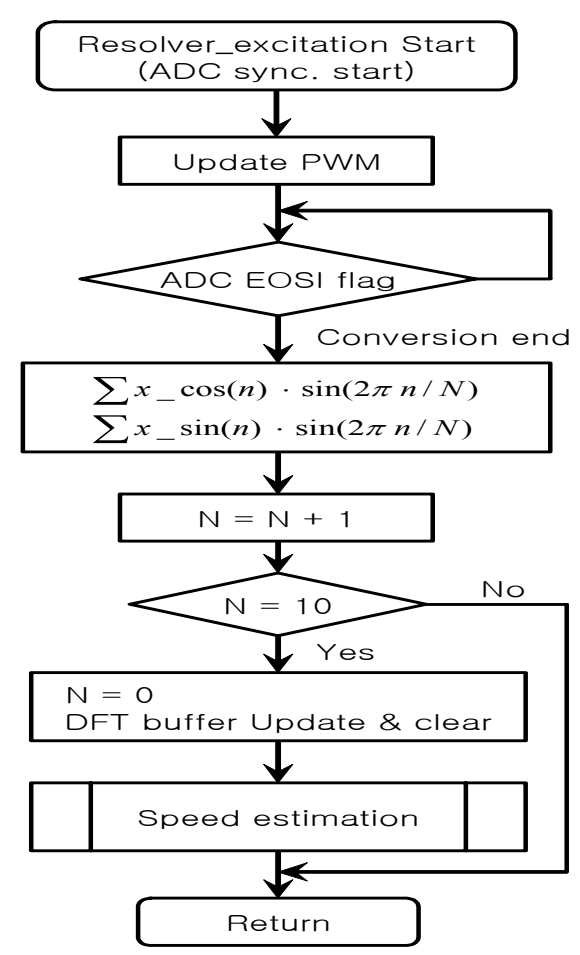

[그림 11] 프로그램 순서도

[Fig. 11] Program flowchart

본 연구에서도 속도의 추정을 PI제어기에 의한 방법을 사용한다. 회전자의 위치변화와 속도는 식 (12)와 같다.

$$
\frac{d \theta}{d t}=\omega
$$

식 (12)에서 식 (17)로 계산된 회전자의 위치와 추정값 의 회전자 오차가 0 이 되도록 PI제어기에 의하여 속도를 추정하면 식 (13)과 같다.

$$
\frac{d \hat{\theta}}{d t}=\left(k_{p}+\frac{k_{i}}{s}\right)(\theta-\hat{\theta})
$$

그림 12는 속도 추정기를 나타내었다.

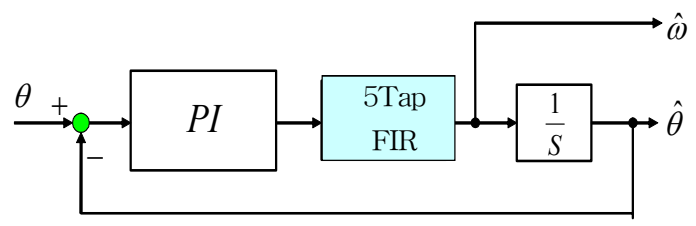

[그림 12] 속도 추정기

[Fig. 12] Speed estimator

\subsection{6 여자회로와 신호처리.}

디지털처리를 위하여 아날로그회로는 최소한의 회로 를 사용하며 레졸버의 여자회로와 $\mathrm{A} / \mathrm{D}$ 입력을 위한 필터 로 구성한다. 여자신호는 그림 13과 같이 샘플링간격으 로 변조된 $\mathrm{PWM}$ 을 필터링하여 여자신호로 사용하며, 입 력회로는 노이즈를 제거하기위하여 차동신호입력의 필터 를 사용한다. $\mathrm{A} / \mathrm{D}$ 변환기에 의하여 변환 입력된 디지털신 호에 의하여 회전자의 위치와 속도를 계산 혹은 추정하 여 전동기의 제어에 사용한다.

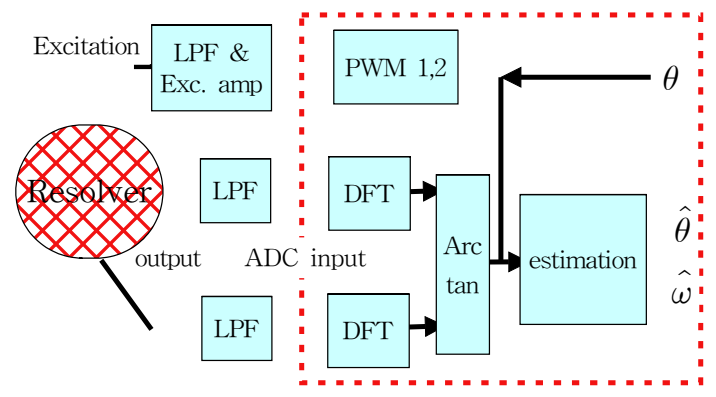

[그림 13] 레졸버 인터페이스

[Fig. 13] Resolver interface

레졸버 신호는 회전자의 수 $[\mathrm{kHz}]$ 의 정현파에 의하여 여자 된 구조의 회전자가 되며 회전자의 위치에 따라 두 개의 권선에서 2 상의 신호를 출력하며 입력인 여자신호 에 대하여 지연각을 갖고 있다. 또 어떤 순간이던 두 신 호는 위치에 대한 정보를 가지고 있기 때문에 신호를 샘 플링하면 회전자의 위치가 계산된다. 그러나 레졸버가 장 착되는 부위는 자계 등 노이즈로부터 취약한 장소이므로 신호에 상당한 외부잡음을 고려하여야 한다. 일반적으로 레졸버는 브러시가 없는 구조로 되어 있으며 회전변압기 에 의하여 회전자권선을 여자 시키는 구조와 회전자에 권선이 없는 구조가 있다. 외부의 회로와 사용은 두 가지 모두 같은 방법으로 사용이 가능하게 된다.

그림 13 의 레졸버 인터페이스에서 그림 14 의 순서도 로 레졸버를 여자 시키고 출력신호를 입력하여 파형의 기본파를 계산한다. 속도의 추정프로그램에서 식 (17)에 의한 회전자의 위치를 계산한다. 계산된 위치정보의 변화 에 대하여 그림 12 의 추정기에 의하여 속도를 계산한다. 회전속도의 추정방법은 관측기를 이용하는 방법과 관측 기를 사용하지 않는 방법들이 있다.

관측기를 사용하는 경우 부하 또는 관성이 변하는 시 스템일 때 관측기의 상수가 변하게 되고 사용하고자 하 는 대상의 장치가 달라지면 상수를 변경시켜야 하므로 범용의 속도검출방법이 되지 않는다. 따라서 부하 및 관 성을 고려하지 않는 $\mathrm{RD}$ 컨버터에서는 관측기를 사용하 
지 않는 방법들이 사용되고 있다.

\subsection{7 회전자의 위치계산}

$\mathrm{DFT}$ 에 의한 $\mathrm{k}$ 차 고조파는 실축과 허축성분으로 식 (14)와 같다.

$$
X(k)=\operatorname{Re} X(k)+j \operatorname{Im} X(k)
$$

그림 2 의 여자전류를 기준으로 한 레졸버의 출력신호 는 식(14)에 의하여 기본파는 식(15)로 계산된 크기와 위 상을 갖게 된다.

$$
\left\{\begin{array}{l}
\operatorname{Re} X(1)=\frac{2}{N} \sum_{n=0}^{N-1} x(n) \cos (2 \pi n / N) \\
\operatorname{Im} X(1)=\frac{2}{N} \sum_{n=0}^{N-1} x(n) \sin (2 \pi n / N) \\
\operatorname{Mag}[X(1)]=\sqrt{\operatorname{ReX}(1)^{2}+\operatorname{Im} X(1)^{2}} \\
\phi[X(1)]=\tan ^{-1} \frac{\operatorname{Im} X(1)}{\operatorname{ReX}(1)}
\end{array}\right.
$$

그림 2의 레졸버 출력은 2상의 신호이므로 한 개는 $\sin$, 다른 한 개는 $\cos$ 파형으로 두 개의 신호이므로 식 (16)에 의한 회전자의 위치를 계산한다. 식(16)은 식(17) 과 같이 계산되므로 그림 2에서 여자신호에 대한 출력신 호의 지연은 회전자의 위치에 영향을 주지 않는다.

$$
\begin{aligned}
\theta & =\tan ^{-1} \frac{\operatorname{Mag}[X(\sin )]}{\operatorname{Mag}[X(\cos )]} \\
& =\tan ^{-1} \frac{\operatorname{ReX}(\sin )}{\operatorname{ReX}(\cos )}
\end{aligned}
$$

레졸버 신호의 복조는 식(15)의 실수축 성분의 계산으 로 완성되며 퓨리에 급수에 의한 방법이므로 지연이 없 는 필터효과를 기대할 수 있다. 따라서 식(17)에 의하여 계산된 회전자의 위치는 전동기의 제어에 직접 사용한다.

\section{3. 실험결과}

제어기에서 프로그램에 의하여 속도를 변화시키는 방 법으로 스텝응답을 측정하였다. 응답을 관찰하면서 속도
추정기인 PI제어기의 이득을 결정하였다. 속도추정기의 이득은 응답성과 정밀성이 관계된다. 전동기 제어프로그 램의 일부분으로 사용하였으나 속도검출기 전용의 경우 와 같이 샘플링간격을 짧게 할 수 있다면 더욱 정밀성의 향상이 가능할 것이다. 실험 결과 속도 추정기로써 넓은 범위의 피드백 이득범위를 갖는 안정성 및 빠른 수렴의

\begin{tabular}{|c|c|c|c|}
\hline \multicolumn{2}{|c|}{ 종 } & 크 기 & 단 위 \\
\hline \multirow{3}{*}{ 전동기 } & 출력 & 5 & {$[K W]$} \\
\hline & 토크 & 23.7 & {$[\mathrm{Nm}]$} \\
\hline & 최대토크 & 71.2 & {$[\mathrm{Nm}]$} \\
\hline \multicolumn{2}{|c|}{ 부하관성 } & 7.2 & {$\left[\mathrm{Nms}^{2} / \mathrm{rad}\right]$} \\
\hline
\end{tabular}
특징이 확인 되었다. 실험에 사용된 전동기와 부하장치는 표 1 과 같다. 전동기의 정-역 운전 및 구동 토오크의 스 텝가변에 대하여 또 측정범위를 확대하여 극 저속에서 속도검출기의 성능을 관찰하였다.

[표 1] 실험장치

[Table 1] Experiment device

그림 14 는 레졸버의 여자주파수를 $11[\mathrm{KHz}]$ 로 했을 때 여자전압과 출력파형을 측정한 것이다. 하단은 상단의 일 부분을 확대한 것이다.

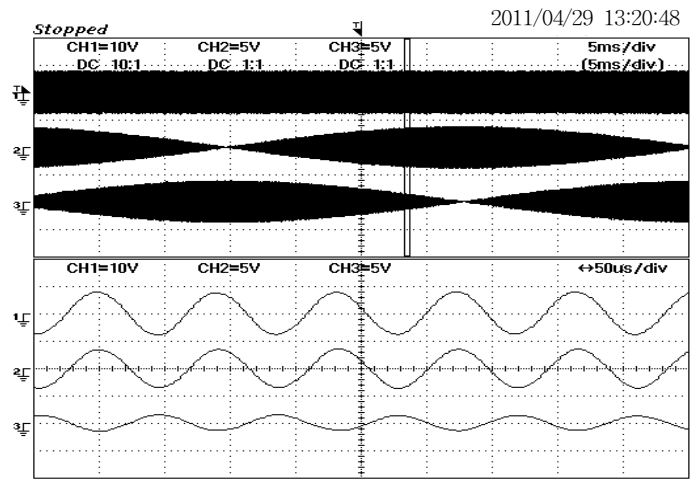

[그림 14] 레졸버의 여자전압과 출력

[Fig. 14] Exite voltage and output of resolver

그림 15 와 그림 16 은 표 1 에 대한 실험 장치에 의하여 극 저속에 대한 속도의 검출결과를 측정한 것이다. 설정 토크의 가변으로 가속도를 변화시키면서 정 역 운전할 때 추정속도를 $17.5[\mathrm{rpm}]$ 의 범위로 확대하여 측정하였으 며 회전속도가 빨라서 측정범위를 벗어난 경우는 최대측 정범위로 제한하여 측정되도록 하였다. 레졸버는 회전자 의 절대위치를 검지할 수 있는 특징을 갖고 있다. 따라서 
동기전동기를 제어할 때와 같이 항상 자극의 위치를 알 고 있어야 하는 제어에 적합하다. 실제 사용에 있어서 노 이즈에 강하다 라는 레졸버의 생산자측의 제안이 있지만 전력변환기의 노이즈에 대하여 작은 신호의 아날로그신 호를 처리해야 하는 부담이 있다.

본 연구에서와 같이 아날로그신호를 전송하여 제어기 의 $\mathrm{A} / \mathrm{D}$ 변환기에 연결하는 방법에 있어서 필터와 차동입 력 및 차동신호의 전송방법이 유용함이 확인되었다.
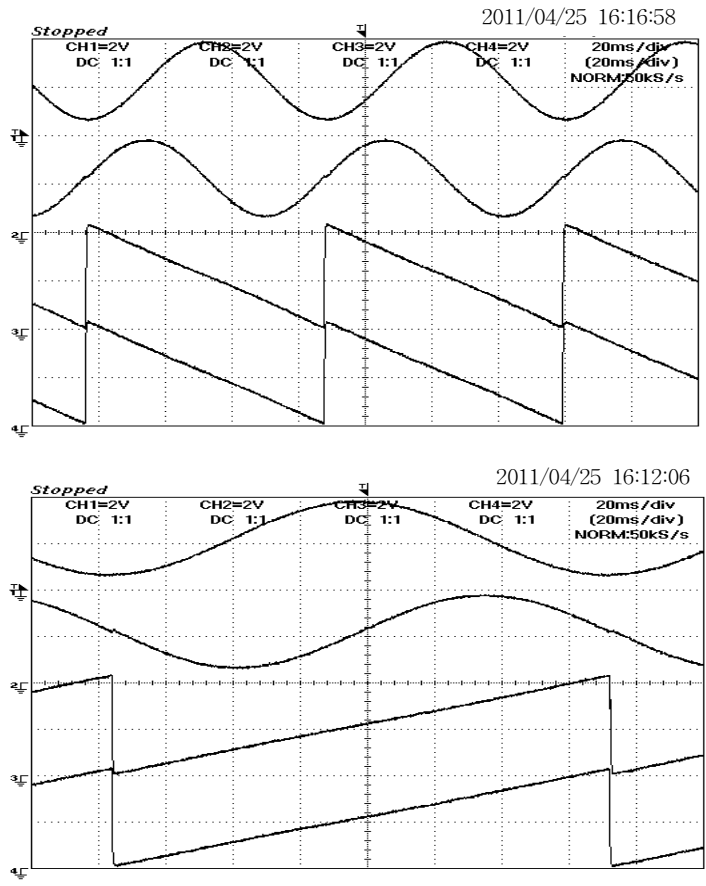

[그림 15] 정회전의 경우 위치추정

[Fig. 15] Position estimation in case of a revolution

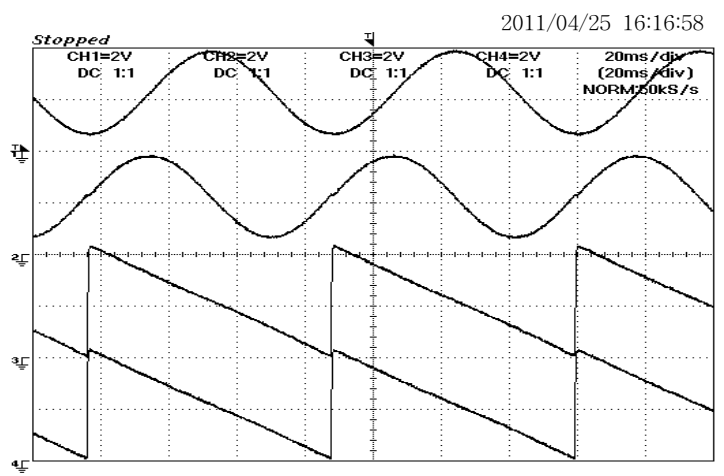

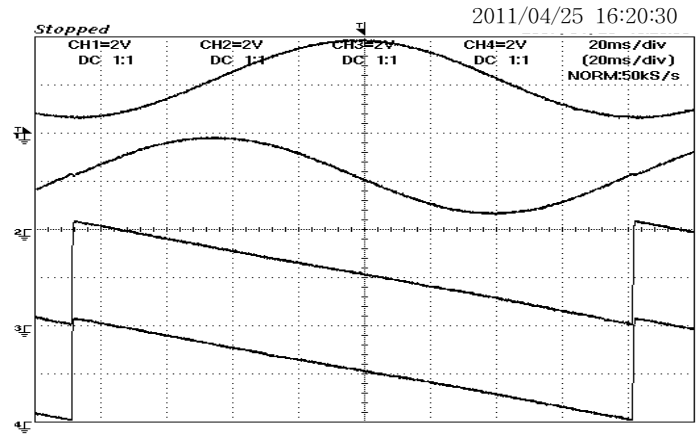

[그림 16] 역회전의 경우 위치추정

[Fig. 16] Position estimation in case of a backlashing (counter)

그림 17 과 그림 18 의 측정파형으로부터 아날로그신호 의 처리와 직접적인 각도의 계산 $\left(\tan ^{-1}\right)$ 으로도 위치정 보로의 사용이 가능함이 확인된다. 전송된 아날로그신호 에 의하여 계산된 위치와 추정된 위치를 확대하였을 때 그림 19 와 같이 측정되었다. 관측기에 의하여 노이즈의 제거가 확인되고 있다.

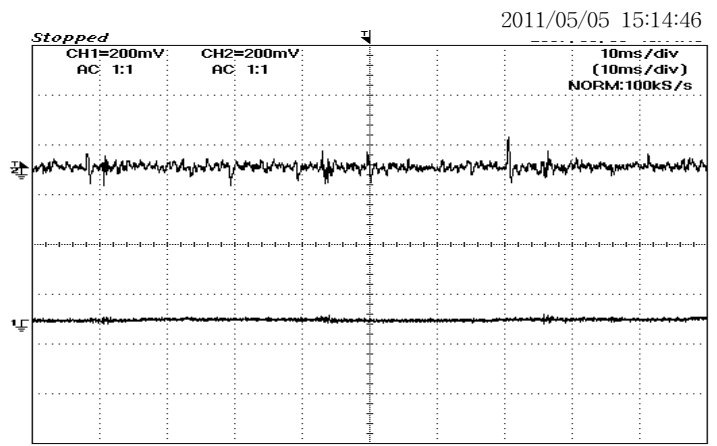

[그림 17] 계산된 위치와 추정된 위치

[Fig. 17] Accounts position and estimated position

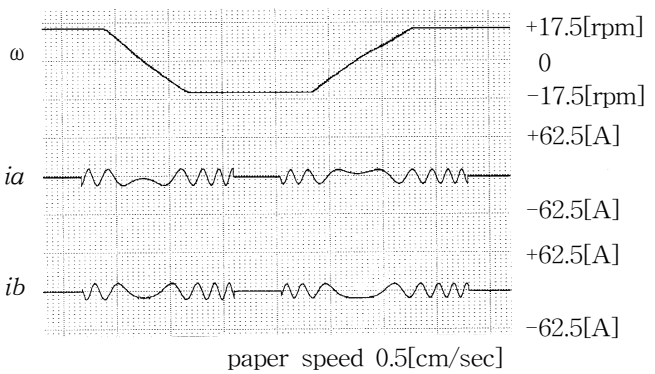

[그림 18] 정, 역순간의 속도검출(낮은 가속도)

[Fig. 18] Speed detection(low acceleration) of regular and a reversal moment 


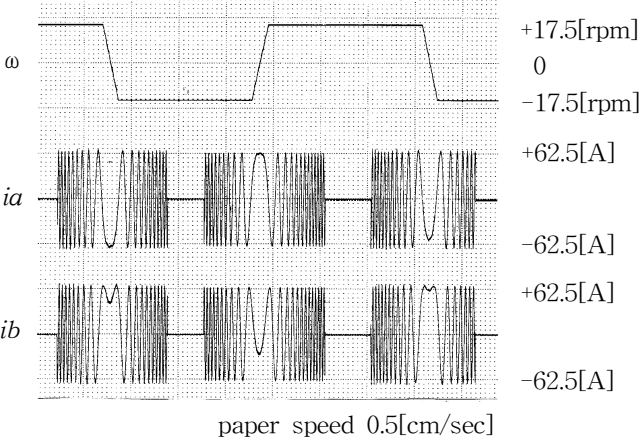

[그림 19] 정,역순간의 속도검출(높은 가속도)

[Fig. 19] Speed detection(high acceleration) of regular and a reversal moment

그림 20 은 PWM 출력과 필터 후 레졸버에 가해지는 여자신호를 측정한 것이다. 샘플링은 $10[\mathrm{us}]$ 이고 여자신 호의 주파수는 $10[\mathrm{kHz}]$ 로 하였다. 속도추정기의 PI이득 을 조정하기 위하여 그림 12 의 입력인 회전자의 위치를 변화시켜 응답을 관찰하였다. 속도와 위치는 최대값을 $5[\mathrm{~V}]$ 로 하여 측정하였다. 그림 21 은 측정범위를 $\pm 1200[\mathrm{rpm}]$ 으로 하고 속도의 스텝변화에 대한 추정기의 응답을 그림 22 는 속도를 가속과 감속했을 때 속도와 위 치의 추정을 측정한 것이다. 그림 23 은 정지 상태에서 정 밀성을 관찰한 것이며 $16[\mathrm{bit}]$ 데이터에서 속도는 하위 $6[\mathrm{bit}]$, 위치는 하위 4[bit]를 측정하였다. 속도는 $12[\mathrm{bit}$, 회전자의 위치추정은 15 [bit]정도의 정밀성을 보이고 있 다. 실험결과 추정기의 이득을 낮출수록 응답성은 저하되 지만 정밀성이 향상됨이 관찰되었다.

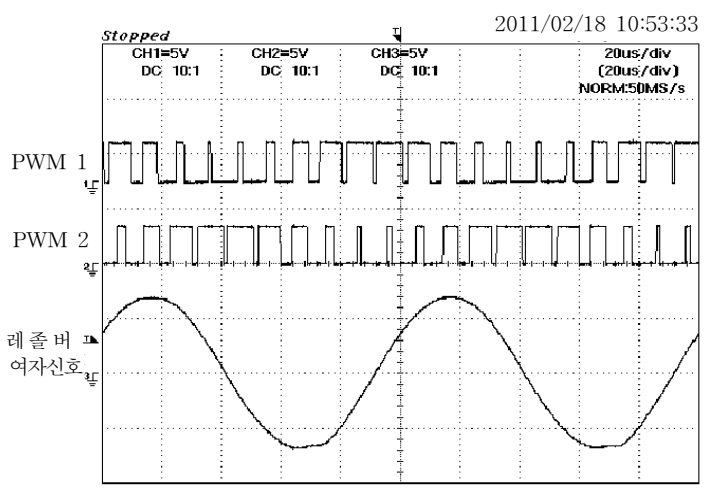

[그림 20] 레졸버의 여자신호

[Fig. 20] Exite signal of resolver

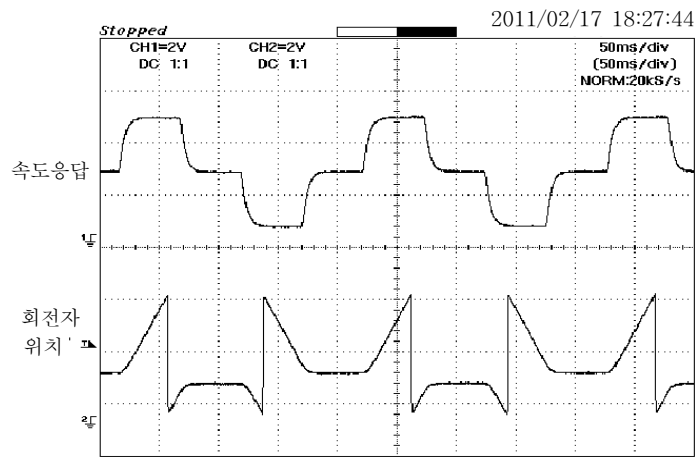

[그림 21] 스텝 응답

[Fig. 21] Step response

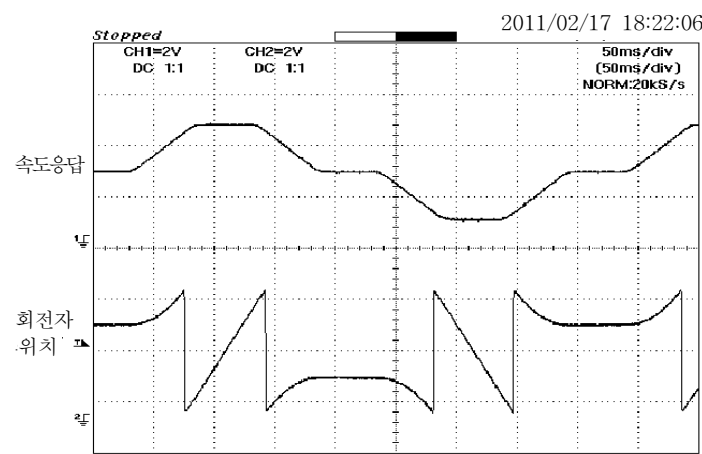

[그림 22] 속도 응답

[Fig. 22] Speed response

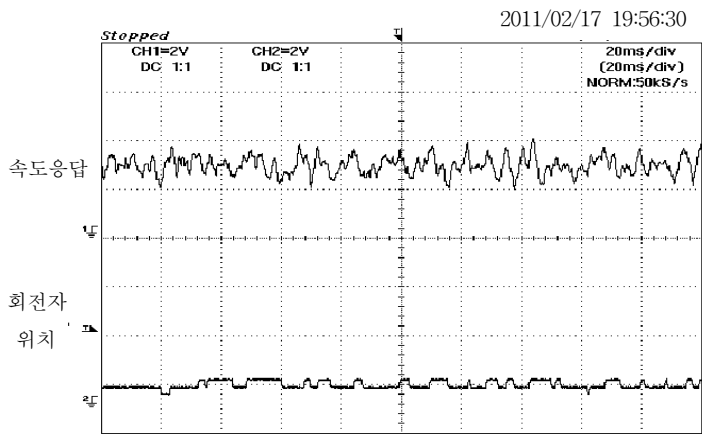

[그림 23] 회전자가 정지한 경우 출력

[Fig. 23] Output in case of stop a rotor

\section{4. 결론}

제어기에는 전동기제어용의 16 비트의 정수 DSP 마이 크로프로세서인 모토롤라의 $56 \mathrm{~F} 8346$ 를 사용하고 개발소 프트웨어를 효과적으로 활용하기 위한 환경을 구축하였 
다. 전력변환기의 제어에 필요한 어셈블러함수를 개발하 고 이를 운용하며, $\mathrm{C}$ 언어의 개발환경에서 어셈블러 함 수를 호출하는 형태로 프로그램을 운용하도록 하고 벡터 제어의 방법으로 제어프로그램을 개발하였다. 제어기에 서 프로그램에 의하여 속도를 변화시키는 방법으로 스텝 응답을 측정하였다. 응답을 관찰하면서 속도추정기인 PI 제어기의 이득을 결정하였다. 속도추정기의 이득은 응답 성과 정밀성이 관계된다. 전동기 제어프로그램의 일부분 으로 사용하였으나 속도검출기 전용의 경우와 같이 샘플 링간격을 짧게 할 수 있다면 더욱 정밀성의 향상이 가능 할 것이다. 실험 결과 속도 추정기로서 넓은 범위의 피드 백 이득범위를 갖는 안정성 및 빠른 수렴의 특징이 확인 되었다. $\mathrm{A} / \mathrm{D}$ 변환된 데이터를 $\mathrm{DFT}$ 에 의하여 기본파를 얻 고 이에 의한 계산으로 위치정도는 12 [bit]이상의 정밀도 가 얻어졌다. 부하의 조건과 관계없는 속도의 추정이므로 범용의 속도검출기 또는 부하 및 관성이 변하는 장치에 응용이 가능한 방법으로 사료 된다.

\section{References}

[1] George Ellis, Jens Ohno Krah, "Observer-based Resolver Conversion in Industrial Servo Systems.”,PCIM 2001.

[2] Reza Hoseinnezhad, Peter Harding "A Novel Hybrid Angle Tracking Observer for Resolver to Digital Conversion.”, 44th IEEE Conference on Decision \& Control, and the European Control Conference, pp.7020-7025, 2005.

[3] Texas Instruments, "TMS320F240 DSP Solution forObtaining Resolver Angular Position and Speed.", Application Report SPRA605, February 2000.

[4] Analog Devices, "12-Bit R/D Converter with Reference Oscillator.”, Analog Devices, 2003.

[5] L. Kovudhikulrungsri, T. Koseki, "Improvement of Speed Estimation of an Induction Motor with a Low-Resolution Sensor for Pure Electric Braking System.”, International Conference on Electrical Engineering (ICEE 2001), Vol. 3, pp. 1337-1341, July 2001.

[6] S.Takashi, K.Takafumi, "Simple Train Automatic Stopping Control with Constant Power Braking Pattern Supposing the Pure Electric Brake." I.E.E. Japan 2001 Japan Industry Applications Society Conference (JISAC2001), Vol. 3, pp.1285-1288, August 2001.

[7] L. Kovudhikulrungsri, T. Koseki, "Control of an Induction Motor for Pure Electric Brakes", I.E.E. Japan 2001 Japan Industry Applications Society Conference (JISAC2001), Vol. 3, pp. 1297-1302, August 2001.
[8] S.Sone,T.Koseki, T.Suzuki, H.Iida, K.Hisatomi, A Kaga, "Studies and Issues on Realization of PureElectric Brake of Electric Train", The 38th Symposium on Cybernetics applied to Railway Systems, No. 523, December 2001.

[9] T.Suzuki, T.Koseki, S. Sone, "A Novel Concept of Automatic Train Operation Using a Pure Electric Brake", Jointed Railway Technology Symposium 2001, S9-1-5, pp.419-420, December 2001.

[10] T.Suzuki, T.Koseki, S.Sone, "Evaluation of Influence on Train Running Curves and Regenerative Coefficients Caused by the Constant Power Braking Pattern", I.E.E. Japan Joint Technical Meeting on Transportation \& Electric Railways and ITS, TER-02-12 ITS-02-2, pp. 7-12, March 2002.

\section{황 락 훈(Lark-Hoon Hwang)}

[정회원]

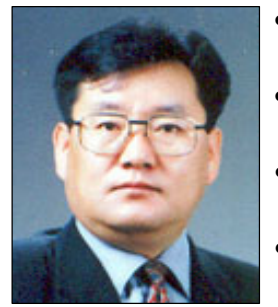

- 1981년 2월 : 명지대학교 전기공 학과 (공학사)

- 1983년 8월 : 명지대학교 대학원 전기공학과 (공학석사)

- 1989년 8월 : 명지대학교 대학원 전기공학과 (공학박사)

- 1988년 3월 1991년 2월 충남 전문대학(현 대덕대학)전기과조 교수

- 1991년 3월 현재 : 세명대학교 전기공학과 교수

<관심분야>

에너지 변환, 전동기 제어, 전력전자 응용분야, 반도체 시뮬레이션 등

\section{나 승 권(Seung-Kwon Na)}

[정회원]

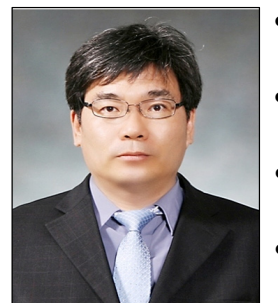

- 1999년 2월 : 세명대학교 전기공 학과(공학사)

- 2001년 2월 : 세명대학교 대학원 전기전자공학과 (공학석사)

- 2008년 2월 : 세명대학교 대학원 전기전자공학과 (공학박사)

- 1981년 7월 1988년 4월 : 부 산위생(한방)병원

- 1988년 5월 1994년 8월 : 한국수자원공사

- 1994년 8월 현재 : 한국 폴리텍 III 대학 원주캠퍼 스 의용공학과 부교수

<관심분야>

의용공학 및 에너지 변환, 전력전자 응용분야 등 
최 기 호(Gi-Ho Choi)

[정회원]

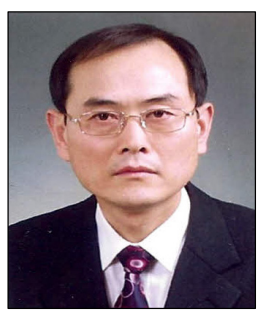

- 2008년 2월 : 세명대학교 대학원 전기전자공학과 (공학석사)

- 1981년 10월 : 한국 폴리텍 II대 학 남인천 캠퍼스 전기제어학과 조교수

- 2008년 2월 현재 : 한국 폴리 텍 III 대학 원주 캠퍼스 전기제 어학과 부교수

<관심분야>

소방설비, 승강기, 전기기기, 전력전자 응용분야 등 